\title{
Determinants of Human Papilloma Virus (HPV) Vaccination among Elementary Students in Central Jakarta
}

\author{
Rini Febrianti ${ }^{1}$, Mugi Wahidin ${ }^{2,3 *}$ \\ ${ }^{1}$ High School of Health Science (STIKES) of Keluarga Bunda, Jambi, Indonesia \\ ${ }^{2}$ University of Esa Unggul, Jakarta, Indonesia \\ ${ }^{3}$ National Institute of Health Research and Development, Ministry of Health, Jakarta, Indonesia
}

\section{ARTICLE INFO}

Received : 16 September 2020

Reviewed : 23 October 2020

Accepted : 01 March 2021

Keywords:

cervical cancer, HPV, vaccination

${ }^{*}$ Corresponding author:

Mugi Wahidin

National Institute of Health Research and Development, Ministry of Health, Jakarta, Indonesia

wahids.wgn@gmail.com

\author{
A BSTRACT
}

\begin{abstract}
Background: Human Papilloma Virus (HPV) is the leading risk factor of cervical cancer. World Health Organization (WHO) has recommended including HPV vaccination in national immunization programs in all countries. Specifically, Jakarta Province has been implementing HPV vaccination since 2016. In this case, several factors influence vaccination coverage. However, there is limited evidence about determinants associated with HPV vaccination. Therefore, this study aimed to investigate the factors associated with HPV vaccination among elementary students in Central Jakarta.
\end{abstract}

\begin{abstract}
Methods: This was a cross-sectional study conducted from March until June 2020. The study population involved 167 female students of the 6th level of the elementary school in Central Jakarta. There were eight elementary schools in Kemayoran and Cempaka Putih Sub Districts selected purposively. Primary data was collected employing an online questionnaire, which was fulfilled by respondents (mothers and students). Data were analyzed utilizing statistic software for descriptive and bivariate analysis. For the bivariate analysis, Chi-Square Test was performed.

Results: The HPV vaccination coverage was $80.84 \%$. It was also showed that the last education level of the respondents' father and mother was mainly senior high school (SMA) for $50.3 \%$ and $47.9 \%$, respectively. The mothers' knowledge was mainly in the middle (56.9\%), and they had a positive attitude/support (67.1\%). There were only $2.4 \%$ of the respondents with a family history of cervical cancer. In terms of family economic status, the main part of respondents had low expenditure for 2-3 million IDR (59.3\%) a month. Meanwhile, human resources (vaccination providers) and HPV vaccine were $100 \%$ available in the vaccination service. Of the respondent, $47.9 \%$ of those said that the vaccine price was affordable. Children who had no support to get HPV vaccination from their father, mother, and siblings were $14.4 \%, 6.6 \%$, and $21.6 \%$, respectively. Besides, children who were not supported by their teachers was $3.6 \%$ and not supported by their peers was $23.4 \%$. Meanwhile, father and mother's supports were significantly associated with HPV vaccination.
\end{abstract}

Conclusions: Factors associated with HPV vaccination were the support from the father and mother.

\section{INTRODUCTION}

Cervical cancer is the second commonest cancer in Indonesia. It was estimated that Indonesia's incidence was 23.4 per 100.000 women in 2020 , with the death rate of 13.9 per 100.000 women [1]. In Jakarta province, the incidence was 9.25 per 100,000 women by 2012 [2]. The disease became one of the main contributors to cancer treatment cost in Indonesia, the 3rd rank. It rose from IDR 1.54 trillion in 2014 became 2.29 trillion in 2015, 2.61 trillion in 2016, and 3.18 trillion in 2017 [3].
The leading risk factor of cervical cancer is the Human Papilloma Virus (HPV). The virus influences initiating stage of the metaplasia process to be cervical cancer in the human body. The carcinogenesis of cervical cancer is started by infection of HPV as the initiator of mutation of cervical cells [4]. HPV is a virus transmitted through sexual intercourse. HPV infection generally occurs in females in reproduction age, with $80 \%$ of which may recover and $20 \%$ becomes a pre-cancer lesion. The infection can lead to cervical cancer between 3 and 17 years after infection [5]. 
Since 2008, World Health Organization (WHO) has recommended including HPV vaccination in national immunization programs in all countries. The vaccination target is girls at the age of 4 until 14 before experiencing sexual intercourse [6]. HPV vaccination is a way to prevent cervical cancer early, but this vaccination does not replace cervical cancer screening [7]. The introduction of HPV vaccination to women in Indonesia will be very beneficial to reduce the burden of cervical cancer, in which the screening of this disease is not adequate [8].

HPV vaccination in Indonesia was started in 2012, and Jakarta Province is one of the provinces implementing HPV vaccination since 2016. The program's target is female elementary students in the 5th level for the first dose and the 6th level for the second dose. The vaccine, a quadrivalent vaccine for type $6,11,16$, and $18 \mathrm{HPV}$, is given at 0-12 months for children aged nine until 13 years [9]. By 2017, coverage of the vaccination in Jakarta among the 5th level of elementary school was $89.4 \%$, and the coverage of Central Jakarta was $90.1 \%$. It was higher than national coverage at $70.9 \%$ [10]. The coverage indicates that there are some children in Jakarta, especially in Central Jakarta, who have not received the vaccination.

HPV vaccination coverage is influenced by several factors. In low middle-income countries, the vaccination is influenced by sociocultural, health, and political support [11]. A study in Kediri, East Java, Indonesia, showed that education, knowledge, and family support were associated with HPV vaccination [12]. In Asia Pacific countries, women's susceptibility to HPV infection, knowledge of safety and effectiveness of the vaccine, social consequences, and peer support were associated with the willingness to get the HPV vaccine [13]. Nevertheless, there is limited evidence about determinants associated with HPV vaccination, especially in Jakarta, a metropolitan city. Jakarta's population has a unique characteristic that many ethnicities from all areas in Indonesia are there. Therefore, this study aimed to investigate factors associated with HPV vaccination among elementary schools in Central Jakarta.

\section{METHODS}

This observational study used the design of a crosssectional study. The study was conducted in Central Jakarta from March until June 2020. Female students of the 6th level of the elementary school in Central Jakarta became the study population. The main respondents of this study were the students' mothers. The researchers took a sample of elementary schools purposively with the criteria that the school had low coverage of HPV vaccination (under $90 \%$ ) from private and public schools. The respondent's eligibility criteria were respondents who could use a mobile phone and willing to be respondents. There were eight selected elementary schools in Kemayoran and Cempaka Putih Sub Districts: 1) SD Muhammadiyah, Kebon Kosong, 2) SDN 03 Serdang, Kemayoran, 3) SDN 11 Serdang, 4) SDI Qatrunada, 5) SDN Sumur Batu 12, 6) SDN Sumur Baru 14, 7) SD Anglo Cempaka Putih Barat, and 8) SDN Cempaka Putih Barat 19. The sample of the study was the total population from the 6th level of the selected schools. Thus, a total of 167 mothers and 167 female students were included in this study using sample size tests of two population proportions [14]. Mothers answered the identity questions, including father and mother's last education, HPV vaccination, knowledge, attitude, and vaccine affordability. Meanwhile, the students answered questions of support from family, teachers, and friends.

Primary data were collected using an online questionnaire (self-administered), which was fulfilled by respondents (mothers and students). Data were analyzed utilizing statistic software (SPSS 16.0) for descriptive, bivariate, and multivariate analysis. Descriptive analysis was performed to explore the frequency of dependent variable (HPV vaccination) and independent variables, including father's last education, mother's last education, mother's knowledge, mother's attitude, family expenditure, vaccine's availability, vaccination providers' availability, vaccine's affordability, and support from father, mother, siblings, teachers, and peers. Knowledge was categorized as high (score $\geq 80$ ) for correct answers, medium (score of 60-79), and low (<60). Besides, family expenditure is a proxy of the household's economic status. The attitude was categorized as positive (score $\geq$ median) and negative (score <median). The bivariate analysis was then performed to know the association between independent variables with a dependent variable using Chi-Square Test with .05 significance.

This study was conducted based on ethical clearance from the University of Esa Unggul Jakarta No. 0144.20.114/DPKE-KEP/FINAL-EA/UEU/IV/2020.

\section{RESULTS}

The descriptive analysis results showed that HPV vaccination coverage was 80.84\% (135 of 167 respondents), and there were 32 of 167 respondents (19.16\%) who have not received the HPV vaccination.

The analysis results also showed that the last education level of the respondents' father and mother was mainly senior high school (SMA) for 50.3\% and $47.9 \%$, respectively. The mother's knowledge was mainly in the middle $(56.9 \%)$, and they had a positive attitude/ support (67.1\%). There was only $2.4 \%$ of the respondents have a family history of cervical cancer. In terms of 
family economic status, the main part of respondents had low expenditure for 2-3 million IDR (59,3\%) a month. Meanwhile, human resources (vaccination providers) and HPV vaccine were $100 \%$ available in the vaccination service. Of the respondent, $47.9 \%$ of those said that the vaccine price was affordable. Children who had no support to get HPV vaccination from their father, mother, and siblings were $14.4 \%, 6.6 \%$, and $21.6 \%$, respectively. Meanwhile, children who were not supported by their teachers was $3.6 \%$ and not supported by their peers was $23.4 \%$ (Table 1 ).

Moreover, the bivariate analysis results suggested that father and mother's supports were significantly associated with HPV vaccination $(P<.05)$ with a prevalence ratio (PR) of $1.45(95 \% \mathrm{Cl} 1.03-2,05)$ and 1.83 (95\% $\mathrm{Cl} 0.96$ - 3.15), respectively. Other variables were not associated with HPV vaccination $(P>.05)$ : father's last education, mother's last education, mother's knowledge, mother's attitude, family expenditure, family history of cervical cancer, vaccine's affordability, and support from siblings, teacher, and peers (Table 2 ).

\section{DISCUSSION}

Coverage of HPV vaccination among the 6th elementary school level in Central Jakarta was $80.84 \%$ or $19.16 \%$ of those who have not got the vaccination. This coverage was lower than reported data in 2017, stating that the Jakarta Province coverage was $89.4 \%$ and Central Jakarta was $90.1 \%$. This coverage was also lower than coverage in Kulonprogro Regency, Yogyakarta province (99.8\%), Gunung Kidul Regency (99.7\%), Surabaya City (95.1\%), and Bandung Regency (94.8\%) [10].

The coverage seemed higher than a study in Badung Regency, Bali, in 2017 on HPV vaccination for senior high school (10th level), revealing that $92.2 \%$ of those had not received the HPV vaccination [15]. Similarly, a study in Yogyakarta in the same year uncovered that female adolescents' willingness to get HPV vaccination was only $9.9 \%$. The halal issue was the most consideration to participate in the vaccination [16]. A study among elementary and junior high schools in Sleman, Yogyakarta, in 2017, disclosed that willingness to get HPV vaccination was still low (42.5\%). The factor associated with intention to the vaccination was the attitude. Meanwhile, the factor that became a consideration to uptake HPV vaccination was the vaccine's safety [17].

The respondents' parents of this study mainly had an education of senior high school (middle). It indicated that they could understand the HPV vaccination's benefits and their daughter's risk of getting cervical cancer if they did not get the vaccine. Similarly, mothers'
Table 1. Characteristics of study participants

\begin{tabular}{|c|c|c|}
\hline Variable & $\mathbf{N}$ & $\%$ \\
\hline \multicolumn{3}{|l|}{ Last education of father } \\
\hline$\leq$ Elementary School & 2 & 1.2 \\
\hline Junior High School & 36 & 21.6 \\
\hline Senior High School & 84 & 50.3 \\
\hline University & 45 & 26.9 \\
\hline \multicolumn{3}{|l|}{ Last education of mother } \\
\hline$\leq$ Elementary School & 22 & 13.2 \\
\hline Junior High School & 22 & 13.2 \\
\hline Senior High School & 80 & 47.9 \\
\hline University & 43 & 35.7 \\
\hline \multicolumn{3}{|l|}{ Knowledge of mother } \\
\hline High & 39 & 23.4 \\
\hline Middle & 95 & 56.9 \\
\hline Low & 21 & 12.6 \\
\hline \multicolumn{3}{|l|}{ Attitude of mother } \\
\hline Positive & 112 & 67.1 \\
\hline Negative & 54 & 32.3 \\
\hline \multicolumn{3}{|c|}{ Family history of cervical cancer } \\
\hline Yes & 4 & 2.4 \\
\hline No & 163 & 97.6 \\
\hline \multicolumn{3}{|l|}{ Family expenditure (IDR) } \\
\hline$<2$ million & 23 & 13.8 \\
\hline 2-3 million & 99 & 59.3 \\
\hline 4-5million & 25 & 15.0 \\
\hline$>5$ million & 18 & 10.8 \\
\hline \multicolumn{3}{|c|}{ Availability of human resources } \\
\hline Yes & 167 & 100 \\
\hline No & 0 & 0 \\
\hline \multicolumn{3}{|c|}{ Availability of HPV vaccine } \\
\hline Yes & 167 & 100 \\
\hline No & 0 & 0 \\
\hline \multicolumn{3}{|c|}{ Affordability of HPV vaccine price } \\
\hline Affordable & 80 & 47.9 \\
\hline Not affordable & 30 & 18.0 \\
\hline \multicolumn{3}{|l|}{ Support from father } \\
\hline Yes & 143 & 85.6 \\
\hline No & 24 & 14.4 \\
\hline \multicolumn{3}{|l|}{ Support from mother } \\
\hline Yes & 156 & 93.4 \\
\hline No & 11 & 6.6 \\
\hline \multicolumn{3}{|l|}{ Support from siblings } \\
\hline Yes & 131 & 78.4 \\
\hline No & 36 & 21.6 \\
\hline \multicolumn{3}{|l|}{ Support from teachers } \\
\hline Yes & 161 & 96.4 \\
\hline No & 6 & 3.6 \\
\hline \multicolumn{3}{|l|}{ Support from peers } \\
\hline Yes & 128 & 76.6 \\
\hline No & 39 & 23.4 \\
\hline
\end{tabular}


Table 2. Association between independent variables with HPV vaccination

\begin{tabular}{|c|c|c|c|c|c|c|c|}
\hline \multirow{3}{*}{ Variable } & \multicolumn{4}{|c|}{ HPV Vaccination } & \multirow{3}{*}{$\begin{array}{l}\text { Total } \\
\text { N }\end{array}$} & \multirow{3}{*}{$\begin{array}{l}\text { PR } \\
\text { (95\% Confidence } \\
\text { Interval) }\end{array}$} & \multirow{3}{*}{$P$} \\
\hline & \multicolumn{2}{|c|}{ Yes } & \multicolumn{2}{|c|}{ No } & & & \\
\hline & $\mathbf{N}$ & $\%$ & $\mathbf{N}$ & $\%$ & & & \\
\hline Last education of father & & & & & & - & 0.445 \\
\hline$\leq$ Elementary School & 2 & 100 & 0 & 0.0 & 2 & & \\
\hline Junior High School & 26 & 72.2 & 10 & 27.8 & 36 & & \\
\hline Senior High School & 69 & 82.1 & 15 & 17.9 & 84 & & \\
\hline University & 38 & 84.4 & 7 & 15.6 & 45 & & \\
\hline Last education of mother & & & & & & - & 0.166 \\
\hline$\leq$ Elementary School & 14 & 63.6 & 8 & 36.4 & 22 & & \\
\hline Junior High School & 19 & 86.4 & 3 & 13.6 & 22 & & \\
\hline Senior High School & 67 & 83.8 & 13 & 16.2 & 80 & & \\
\hline University & 35 & 81.4 & 8 & 18.6 & 43 & & \\
\hline Knowledge of mother & & & & & & - & 0.724 \\
\hline High & 33 & 84.6 & 6 & 15.4 & 39 & & \\
\hline Middle & 77 & 81.1 & 18 & 18.9 & 95 & & \\
\hline Low & 16 & 76.2 & 5 & 23.9 & 21 & & \\
\hline Attitude of mother & & & & & & $1.07(0.90-1.26)$ & 0.547 \\
\hline Positive & 93 & 83.0 & 19 & 17.0 & 112 & & \\
\hline Negative & 42 & 77.8 & 12 & 22.2 & 54 & & \\
\hline Family history of cervical cancer & & & & & & $1.24(1.15-1.34)$ & 1.000 \\
\hline Yes & 4 & 100 & 0 & 0 & 4 & & \\
\hline No & 131 & 80.4 & 32 & 19.6 & 163 & & \\
\hline Family expenditure (IDR) & & & & & & - & 0.466 \\
\hline$<2$ million & 16 & 69.6 & 7 & 30.4 & 23 & & \\
\hline 2-3 million & 83 & 83.8 & 16 & 16.2 & 99 & & \\
\hline 4-5million & 20 & 80.0 & 5 & 20.0 & 25 & & \\
\hline$>5$ million & 14 & 77.8 & 4 & 22.2 & 18 & & \\
\hline Affordability of HPV vaccine prize & & & & & & $0.99(0.82-1.19)$ & 1.000 \\
\hline Affordable & 66 & 82.5 & 14 & 17.5 & 80 & & \\
\hline Not affordable & 25 & 83.3 & 5 & 16.7 & 30 & & \\
\hline Support from father & & & & & & $1.45(1.03-2.05)$ & 0.009 \\
\hline Yes & 121 & 86.4 & 22 & 15.4 & 143 & & \\
\hline No & 14 & 58.3 & 10 & 41.7 & 24 & & \\
\hline Support from mother & & & & & & $1.83(0.96-3.15)$ & 0.007 \\
\hline Yes & 130 & 83.3 & 26 & 16.7 & 156 & & \\
\hline No & 5 & 45.5 & 6 & 54.5 & 11 & & \\
\hline Support from siblings & & & & & & $1.15(0.93-1.43)$ & 0.214 \\
\hline Yes & 109 & 83.2 & 22 & 16.8 & 131 & & \\
\hline No & 26 & 72.2 & 10 & 27.8 & 36 & & \\
\hline Support from teachers & & & & & & $1.64(0.73-3.66)$ & 0.085 \\
\hline Yes & 132 & 82.0 & 29 & 18.0 & 161 & & \\
\hline No & 3 & 50.0 & 3 & 50.0 & 6 & & \\
\hline Support from peers & & & & & & $1,22(0.98-1.52)$ & 0.061 \\
\hline Yes & 108 & 84.4 & 20 & 15.6 & 128 & & \\
\hline No & 27 & 69.2 & 12 & 30.8 & 39 & & \\
\hline
\end{tabular}


knowledge was mainly in the middle and had a positive attitude or supported the vaccination. It became positive aspects to encourage them to support their children to get a vaccination. These findings corroborate with a study among university students in Semarang, which showed that respondents had less knowledge about cervical cancer and HPV vaccination, but most respondents were willing to receive the HPV vaccination [18].

Only $2.4 \%$ of the respondents had a family history of cervical cancer, which becomes a challenge to educate the parents to understand the risk of cervical cancer for their children. The respondents were mainly in the low part in terms of expenditure for 2-3 million IDR a month. It did not become a problem because the vaccine was now free of charge, covered by the local government. There was also no problem with the availability of human resources and vaccines in PHC. This condition becomes a strength to scale up the vaccination coverage. However, many children had no support to get HPV vaccination from their father, mother, and siblings. It is a challenge for the provincial health office, district health office, and PHC to strengthen socialization and education for students' families.

Previously, a qualitative study in Uganda showed that these were major motivations for girls' and parents' acceptance of HPV vaccination. Parents' increased awareness that HPV is sexually transmitted encouraged their support for their adolescent daughters' vaccination against HPV. However, there were reports of some initial fears and misconceptions about HPV vaccination, especially during its introduction. It initially discouraged some parents and girls, but over the years, with no major side effects reported, girls reported that they were willing to recommend the vaccination to others, and parents also reported their willingness to get their daughters vaccinated without fear [19].

Factors that had an association with HPV vaccination were support from the father and mother. This result is in line with Green's theory that family support is one of the reinforcing factors of behavior, including healthseeking behavior [20]. It is also not different from a study using a systematic review in Asia Pacific countries that peer support was correlated with willingness to get HPV vaccine [13]. Moreover, a study in Kediri, East Java, showed that education, knowledge, and family support were associated with HPV vaccination [12]. Meanwhile, a study in Badung Regency, Bali, revealed that knowledge and attitude were associated with HPV vaccination among senior high school students [15].

Furthermore, a study among Dutch girls in 2013 uncovered that social-psychological determinants largely contributed to the explained variance of HPV vaccination intention of mothers. Attitudes, beliefs, subjective norms, and habit strength were significantly correlated with participants' HPV vaccination intentions [21] Another study in Netherland suggested that mothers' intention was the strongest predictor of their daughters' HPV vaccination uptake [22]. There is a need to strengthen efforts to increase awareness among parents who have a daughter to allow them to get a vaccination.

This study was based on a self-administered questionnaire (online), in which the respondents (mother and daughter) might influence other families in answering the questions. When fulfilling the forms, especially question about support, the daughter might discuss with their father or mother. These conditions might produce bias of information in this study.

\section{CONCLUSIONS}

Based on bivariate analysis, the factors associated with HPV vaccination among the 6th elementary school level in Central Jakarta were the father and mother's support.

\section{DECLARATIONS}

\section{Competing of Interest}

The authors declare that no conflict of interest in this study.

\section{Acknowledgment}

Thank you for Ministry of Research and Technology, Ministry of Education, Provincial Education Office of Jakarta, Provincial Health Office of Jakarta, Central Jakarta Education Office, Central Jakarta Health Office, Primary Health Center of Kemayoran, Primary Health Center of Cempaka Putih, that allowed and supported this research.

\section{REFERENCES}

1. IARC. Globocan 2018: Population Fact Sheet. [Internet]. France: IARC [cited 2020 March 1] Available from: https://gco.iarc.fr/today/fact-sheetspopulations

2. Wahidin M, Noviani R, Hermawan $S$, et al. Population-based cancer registration in Indonesia. Asian Pac J Cancer Prev. 2012;13:1709-10.

3. BPJS. Report of BPJS Kesehatan 2018. 2019.

4. Rasjidi I. Epidemiologi Kanker pada Wanita. Jakarta: CV Sagung Seto; 2010.

5. Kemenkes. Pedoman Teknis Pengendalian Kanker Payudara dan Kanker Leher Rahim. 2013;

6. WHO. Introducing $\mathrm{Hpv}$ Vaccine Into National Immunization Programmes [Internet]. World Health 
Organization. Geneva; 2016. 104 p. Available from: www.who.int/immunization/documents

7. WHO. Comprehensive Cervical Cancer Control: A Guide to Essential Practice. Geneva; 2006.

8. Setiawan D. HPV vaccination in Indonesia. University of Groningen; 2017.

9. Kemenkes. Peraturan Menteri Kesehatan Nomor 12 tahun 2017 tentang Penyelenggaraan Imunisasi. 2017.

10. Kemenkes RI. Laporan Cakupan Bulan Imunisasi Anak Sekolah per Kabupaten/Kota 2017. Jakarta; 2018.

11. Wigle J, Coast E, Watson-Jones D. Human papillomavirus (HPV) vaccine implementation in low and middle-income countries (LMICs): Health system experiences and prospects. Vaccine. 2013;31(37):3811-7.

12. Sari AP, Syahrul F. Faktor yang berhubungan dengan tindakan vaksinasi hpv pada wanita usia dewasa. J Berk Epidemiol. 2014;2(3):321-30.

13. Young A. HPV vaccine acceptance among women in the Asian Pacific: A systematic review of the literature. Asian Pacific J Cancer Prev. 2010;11(3):641-9.

14. Ariawan I. Besar dan Metode Sampel pada Penelitian Kesehatan. Depok: Fakultas Kesehatan Masyarakat Universitas Indonesia; 1998.

15. Dethan CM, Suariyani NLP. Pengetahuan dan sikap tentang perilaku vaksinasi HPV pada siswi SMA swasta. J MKMI. 2017;13(2):167-75.
16. Arifah K, Damayanti W, Sitaresmi MN. Kesediaan mendapat vaksinasi human papilloma virus pada remaja putri di Yogyakarta. Sari Pediatr. 2017;18(6):430.

17. Wantini NA, Indrayani N. Rendahnya kesediaan vaksinasi hpv pada remaja putri. J Chem Inf Model. 2017;8(9):1-58.

18. Ekowati D, Udiyono A, Martini, Adi MS. Hubungan pengetahuan dengan persepsi mahasiswa dalam penerimaan vaksinasi HPV sebagai upaya pencegahan kanker serviks. J Kesehat Masy. 2017;5(4):334-41.

19. Turiho AK, Okello ES, Muhwezi WW, Katahoire AR. Perceptions of human papillomavirus vaccination of adolescent schoolgirls in western Uganda and their implications for acceptability of HPV vaccination: A qualitative study. BMC Res Notes. 2017;10(1):1-16.

20. Green L, Kreuter M, Deeds S. Health education planning: a diagnostic approach. California: Mayfield Publishing; 1980. xvi, 306 p.

21. Van Keulen HM, Otten W, Ruiter RAC, et al. Determinants of HPV vaccination intentions among Dutch girls and their mothers: A cross-sectional study. BMC Public Health. 2013;13(1):1.

22. Alberts CJ, Van Der Loeff MFS, Hazeveld $Y$, et al. A longitudinal study on determinants of HPV vaccination uptake in parents/guardians from different ethnic backgrounds in Amsterdam, the Netherlands. BMC Public Health. 2017;17(1):1-12. 